\title{
El Trienio Liberal en la monarquía hispánica. Revolución e independencia (1820-1823)
}

José Luis Quezada Lara*

El Colegio de México, México

jquezada@colmex.mx

Pedro Rújula y Manuel Chust, El Trienio Liberal en la monarquía hispánica. Revolución e independencia (1820-1823), Madrid, Catarata, 2020, 189 pp.

Entre 2015 y 2017, mientras redactaba mi trabajo de titulación de la maestría en Historia del Posgrado de la UNAM, con sorpresa descubrí que en México era insuficiente el material bibliográfico que podía consultarse sobre el Trienio Liberal. En ese momento, en bibliotecas podían revisarse los trabajos clásicos que se escribieron varias décadas atrás $\mathrm{y}$, sobre todo, trabajos reunidos en compilaciones sobre el tema. Desde luego, estaba el texto de Gil Novales (1980) y algunos otros como los de Manuel Revuelta (1973) y Vicente Conejero (1983). Aunque no ha pasado mucho tiempo de entonces a la fecha, en ese instante también era escaso lo que podía visualizarse y descargarse en línea. Recuerdo haber consultado de manera fragmentada el trabajo de Marta Ruiz (2007), entre otros. Sin embargo, para fortuna de los interesados en la segunda revolución liberal de España, ambas cosas han cambiado bastante entre 2020 y 2021 por lo que en bibliotecas como la de El Colegio de México o la UNAM pueden consultarse materiales variados.

Como toda conmemoración histórica, es probable que el bicentenario del periodo haya reanimado el interés de los historiadores para acercarse de nueva cuenta al tema. Entre otros trabajos, en 2020, se publicaron los dossiers El Trienio Liberal: 200 años de constitucionalismo y El Trienio Liberal en la prensa

\footnotetext{
${ }^{*}$ Estudiante de doctorado en Historia.
}

(c) (1) (8)

EY Esta obra está protegida bajo una Licencia Creative Commons Atribución-No Comercial 4.0 Internacional 
contemporánea (1820-1823), así como la obra editada por Manuel Chust iMueran las cadenas! El Trienio Liberal en América (1820-1824). Estas obras reúnen textos inéditos de Gérard Dufour, Emilio La Parra, Mario Vázquez, Ivana Frasquet, Andrea Rodríguez, Mariana Terán, entre otros autores. A partir de nuevas perspectivas, estos trabajos buscaron contribuir al debate y renovación historiográfica del periodo mediante el estudio de la recepción del segundo constitucionalismo en España y América, así como la Iglesia, la guerra civil, las elecciones, las escuelas para niños, las publicaciones periódicas y hasta la Inquisición.

Como parte de la euforia editorial derivada de las conmemoraciones, Pedro Rújula y Manuel Chust publicaron, igualmente en 2020, El Trienio Liberal en la monarquía hispánica. Revolución e independencia (1820-1823). El libro es una síntesis histórico-bibliográfica sobre la segunda revolución liberal española. Cuenta con diez capítulos, 190 páginas y una cronología al final de la obra, lo que lo convierte en un buen manual. Cubre el periodo que va del golpe de Rafael de Riego en las Cabezas de San Juan en 1820 a la restauración de Fernando VII como rey absoluto, tras la rendición de Cádiz tres años más tarde. No se aleja de los hechos previamente registrados por la historiografía que trabaja el Trienio. Entre otras cosas, explica la tensión entre el liberalismo institucional del gobierno de las Cortes y el liberalismo popular de los exaltados, la oposición de la Iglesia española y la Santa Sede hacia el régimen liberal en la península, las dificultades del gobierno de las Cortes para estabilizar y expandir su agenda política, el temor de los liberales de una guerra de intervención con las potencias europeas o el rechazo de las insurgencias de América del Sur hacia la solución constitucional que buscaban las Cortes para resolver el "problema americano" (p. 120). Pese a ello, ambos autores indicaron la importancia de la opinión pública en el periodo, aunque bajo la consideración de que esta era naciente por la reactivación de la libertad de imprenta (p. 82). La virtud de su trabajo está en relacionar las ocurrencias del Trienio español con los procesos revolucionarios en América desde una perspectiva política. Por ello, El Trienio Liberal en la monarquía hispánica buscó ofrecer una mirada de conjunto, "como un cruce de caminos en la Historia de España y buena parte de América” (p. 15), sobre 
todo, en el momento en que sus territorios comenzaron a desprenderse como consecuencia de la reactivación constitucional o de sus procesos revolucionarios.

La revisión de las memorias que los ministros de ultramar dirigieron a las Cortes entre 1820 y 1822, documentos que dan cuenta de la situación americana y de sus procesos revolucionarios en términos continentales, les permitieron fundar su interpretación. Mediante ese enfoque advirtieron cómo mientras en Madrid se trataba de fortalecer al régimen liberal y sofocar las conspiraciones instigadas por el rey y el clero, los temas y problemas americanos se fueron insertando en las discusiones de Cortes, marcando las pautas de los debates y hasta determinando el devenir de la monarquía. Un ejemplo de esto se aprecia cuando las Cortes tuvieron noticia de la revolución política que encabezó Iturbide al otro lado del Atlántico o cuando se dejó de recibir el dinero americano en la península con motivo de las independencias, particularmente la mexicana. Por otra parte, el desarrollo de esa perspectiva fue posible gracias a los avances recientes en la historiografía española y la especializada en las insurgencias americanas, las cuales han superado los enfoques nacionales y puesto mayor atención al papel del realismo en América o al de los diputados americanos en la vieja España, entre otros temas.

El Trienio Liberal en la monarquía hispánica. Revolución e independencia (1820-1823), sirve para tener una visión rápida, breve y de conjunto del proceso estudiado. Junto con las obras mencionadas arriba, su libro forma parte de la pléyade de trabajos publicados en el contexto del bicentenario del Trienio. Son pocas las observaciones críticas que tengo para la obra. Diría que la discusión historiográfica es escasa y en ocasiones se echa en falta. En segunda instancia, este es mi señalamiento principal, más que insertar los procesos revolucionarios de América en el marco cronológico y narrativo del Trienio Liberal, extraídos de las memorias escritas por los ministros de ultramar y complementados con bibliografía especializada, hubiese sido interesante que los autores comentaran cuáles fueron las posturas, reacciones, debates y determinaciones del rey, las Cortes y sus Consejos ante los procesos revolucionarios. No obstante, la negativa de las autoridades peninsulares a reconocer las independencias americanas, entre otras cosas, esos documentos muestran cómo el entusiasmo que se tenía en Cortes con la solución 
constitucional para resolver el problema americano pareció desvanecerse ante la irreversibilidad y avance de sus procesos revolucionarios, como claramente ocurrió en la América Septentrional y Meridional (Quezada, 2021, p. 80-81). En todo caso, la interpretación del periodo del Trienio Liberal de ambos autores, quienes asimismo buscaron superar las "interpretaciones conservadoras" y ponderar su vertiente de modernidad y madurez política (pp. 13-14), es sugestiva porque incorporaron a América y sus procesos revolucionarios en una narrativa típicamente peninsular o cuando menos suscrita a las fronteras nacionales de la península.

\section{Referencias}

Chust, M. (ed.). (2020). iMueran las cadenas! El Trienio Liberal en América (18201824). Granada: Editorial Comares.

Conejero Martínez, V. (1983). El Trienio Constitucional en Alicante 1820-1823 y la segunda represión contra los liberales, 1823-1833. Alicante: Caja del ahorro provincial.

Dossier. El Trienio Liberal en la prensa contemporánea (1820-1823). (2020). El Argonauta español, 17. https://doi.org/10.4000/argonauta.3926

Dossier. El Trienio Liberal: 200 años de constitucionalismo. (2020). Historia Constitucional, 21. https://doi.org/10.17811/hc.voi21

Gil Novales, A. (1980). El trienio liberal. Madrid: Siglo XXI.

Quezada Lara, J. L. (2021). La independencia de México vista desde las Cortes del Trienio Liberal, 1820-1822. En L. Canela Morales y H. Strobel (coords.), Los tratados de Córdoba y la consumación de la independencia. Bicentenario de su conmemoración 1821-2021 (pp. 59-84). México: El Colegio de Veracruz/INEHRM.

Revuelta González, M. (1973). Política religiosa de los liberales en el siglo XIX. Trienio constitucional. Madrid: C.S.I.C. Escuela de Historia Moderna.

Ruiz, M. (2007). El liberalismo exaltado: la confederación de comuneros durante el trienio liberal. Madrid: Editorial Fundamentos. 